\title{
Is there a relationship between positive affect and other dimensions of quality of life in colorectal cancer patients?
}

\author{
André Cardoso Louro*, Tomás Blasco y Jordi Fernández-Castro
}

Grup d'Investigació en Estrès i Salut Departament de Psicologia Bàsica. Universitat Autònoma de Barcelona (Spain).

\begin{abstract}
Título: ¿Hay una relación entre estado de ánimo positivo y calidad de vida en enfermos con cáncer colorrectal?

Resumen: La investigación ha evidenciado que las emociones positivas pueden mejorar la salud de pacientes con diferentes enfermedades. El objetivo del presente trabajo es analizar si el estado de ánimo positivo (EAP) está relacionado con la calidad de vida de pacientes con cáncer colorrectal (CRC) y si pueden establecerse directrices para desarrollar intervenciones eficaces que mejoren ese estado de ánimo. Se lleva a cabo una revisión de artículos publicados entre enero de 2001 y Marzo de 2012 a partir de las bases de datos Medline, ISI Web of Knowledge, Psycho Inf y Cochrane y las palabras: emociones positivas, EAP, indicadores de salud, calidad de vida CRC y cáncer. Los artículos se clasificaron en dos grupos: a) Artículos descriptivos; b) Artículos de intervención. Los resultados de los artículos descriptivos indican que el estado de ánimo positivo está relacionado con mejor estado de salud, mejor funcionamiento social, mayor crecimiento personal, mayor bienestar, y menores niveles de ansiedad y depresión. El EAP aumenta cuando se realizan diferentes actividades. Los resultados de los artículos de intervención sugieren que las intervenciones pueden ser adecuadas para mejorar el EAP de los pacientes. Se proporcionan algunas orientaciones que pueden ser útiles para los pacientes con CRC.

Palabras clave: Emociones Positivas; estado de ánimo positivo; interven-
\end{abstract} ciones psicológicas; calidad de vida; cáncer colorrectal.
Abstract: It can be stated from the previous research that positive emotions should allow to better health outcomes in sick populations. The aim of the present work is to know the state-of-the-art of how positive affect (PA) relates with quality of life in colorectal cancer (CRC) patients, as well as to give some guidelines to develop more efficacious psychological interventions in CRC patients to enhance positive affect. This review describes a search of published literature from January 2001 to March of 2012 on the Medline, ISI Web of Knowledge, Psycho Inf and Cochrane databases using publications that contain positive emotions, positive affect, health outcomes, quality of life, CRC and cancer. These articles were classified into two groups: a) “descriptive papers" b) "interventional studies". Results from "descriptive papers" suggest that positive affect (PA) was significantly associated with greater levels of general health, better social functioning, benefit finding, positive changes, low depression, less anxiety and greather psychological well-being. PA also increases when different activities are developed. The overall results from interventional studies suggest that the interventions described can be recommended for improving patient's levels of positive affect. The present review offers some suggestions which could be useful for CRC patients.

Key words: Positive emotions; positive affect; psychological interventions; quality of life; colorectal cancer

\section{Introduction}

Colorectal Cancer (CRC) is a significant cause of morbidity and mortality worldwide (Fitzell \& Pakenham, 2010). In the USA is the third most common cancer found in men and woman (American Cancer Society, 2011) and in Europe, and most of the industrialized world, CRC is the third most common cancer and the third most common cause of cancer deaths (Ferlay et al., 2008). The death rate from colorectal cancer has been going down for more than 20 years. Thanks to colorectal cancer screening, polyps can be found and removed before they turn into cancer. If it is detected in its earlier stages, CRC is highly treatable and potentially curable (American Cancer Society, 2011).

Receiving a cancer diagnosis represents an enormous psychological challenge (Simon, Thompson, Flashman, \& Wardle, 2009). Cancer can affect social relationships (Northouse, Mood, Templin, Mellon, \& George, 2000), which may in turn influence the support the patients receive during their illness (Reynolds \& Perrin, 2004). Cancer and its treatment including surgery/chemotherapy/radiotherapy can also impose a variety of physical and functional disabilities that compromise the patient's ability to work or to maintain independence (Wright, Kiely, Lynch, Cull, \& Selby, 2002).

* Dirección para correspondencia [Correspondence address]:

André Cardoso Louro. Grup d'Investigació en Estrès i Salut. Departament de Psicologia Bàsica. Edifici B. Universitat Autònoma de Barcelona. 08193-Cerdanyola, Barcelona (Spain).

Email: Louro.andre@gmail.com
For cancer patients, psychosocial adjustment involves making life adjustment to adapt to these altered roles and mental changes from the experience of cancer (Nishigaki et al., 2007). In short, both the disease itself and the side effects of interventions produce psychological distress and reduce the quality of life of the patients.

Although "psychological distress" is widely used to refer to the effects produced by cancer and its treatments, its sense varies across researchers. However, it seems that most studies consider that psychological distress includes feelings labeled as "affect" (Hou, Law, \& Fu, 2010), "mood" (Listing et al., 2009), or "emotion" (Cameron, Booth, Schlatter, Ziginskas, \& Harman, 2007). "Affect" is the most used term, referring to a subjective feeling state that incorporates longlasting mood states, such as cheerfulness, depression, happiness or anger. Mood and emotion are generally seen as subtypes of affect, with emotions being more strongly directed toward a specific stimulus - be it a person, an object, or an event (Frijda, 2009). Negative affect has been constructed as a general dimension of subjective distress, reflecting undifferentiated bad moods and low self-concept. Thus, negative affect can be regarded as a category that encompasses traditional concepts such as anxiety, depression, neuroticism, or general maladjustment.

Thus, cancer patients experiencing psychological distress show intense negative affective states (sadness, anger, worries) which can appear at diagnosis, treatment and/or survival stages. Anxiety and depression disturbances can be found in more than $25 \%$ of breast cancer patients (Millar, Purushotham, McLatchie, George \& Murray, 2005), and 
some studies suggest that this proportion can be extended to a 33\% if different kind of tumors are included (Nekolaichuk, Cumming, Turner, Yushchyshyn, \& Sela, 2011). Although no data has been found about which proportion of CRC patients experience negative affective states, there is no reason to not assume that that proportion is similar.

These negative affective states interfere normal activities and could decrease patient's health behaviors (Schofield et al., 2004) and increase treatment side-effects (Blasco, Pallarés, Alonso, \& López López, 2000). Furhtermore, psychological distress could even decrease survival rates in some cancers (Hamer, Chida, \& Molloy, 2009). Thus, interventions addressed to reduce negative affective states have been widespred used in cancer patients (Greer, 2008).

Although "negative affect" (NA) has been the most frequent topic in psycho-oncology research and interventions addressed to psychological distress and quality of life, a new trend has appeared during the last years in the field of health psychology, and authors are also considering "positive affect" when persons experience general levels of well-being, energy, and high activity (Aspinwall \& MacNamara, 2005). The focus of interest has been to know whether positive affect can enhance quality of life and/or decrease emotional disturbances which appear in health problems.

Recent studies have begun to explore the protective effects of positive affect (PA) on physical health, including cardiovascular risk factors, such as hypertension and diabetes and others have suggested an inverse relationship between positive affect and incident stroke and mortality in medical in-patients as well as diabetic patients (Ostir, Markides, Black, \& Goodwin, 2000; Scherer, \& HerrmannLingen, 2009). However, much less is known about the potential impact of positive affect in cancer patients (Penninx et al., 2000; Koenig, 2000), and it is not still well known whether positive emotions would improve quality of life and disease evolution in CRC patients.

The aim of the present work is to know the state-of-theart of how PA relates with well-being and quality of life in CRC patients, as well as to give some guidelines to develop more efficacious psychological interventions in CRC patients.

\section{Method}

This review describes a three-stage review process. First, we conducted a search of published literature from January 2001 to March of 2012 on the Medline, ISI Web of Knowledge, Psycho Inf and Cochrane databases using the following search terms (Cancer OR Colorectal) AND ("Positive Emotions" OR "Positive Affect") AND ("Quality of Life" OR "Health Outcomes"). It was expected to found a larger number of studies assessing CRC patients. However, less than ten studies did it. Thus, all papers will be considered in spite of the kind of cancer patients assessed. From this first search we found 78 articles. Second, the abstract of each resulting article was then read by three researchers and a determination was made by consensus if the study discussed positive emotions or positive affect in cancer patients. From this selection, 35 articles met the inclusion criteria. In the third stage, studies developed only in survivors of cancer were excluded, and theoretical studies which did not provide empirical data were also not considered.

Finally, we select 22 articles which were classified into two groups: a) Studies which described positive emotions assessed in cancer patients and which will be labelled as "Descriptive papers" (13 articles which included 14 studies); b) Studies which applied psychological interventions addressed to enhance positive emotions and that will be labelled "Interventional studies" (9 articles).

\section{Results}

\section{Descriptive Papers}

Table 1 presents the main features of the 14 descriptive studies. It must be stated that in two couples of studies, data provided belonged to the same sample. These were the cases of the Rinaldis' studies (Rinaldis, Pakenham, Lynch, \& Aitken, 2009; Rinaldis, Pakenham, \& Lynch, 2010) and the Schroevers' studies (Schroevers, Kraaij, \& Garnefski, 2008; Schroevers, Kraaij, \& Gamefsky, 2011). However, for the proposal of the present study, they will be considered as independent studies. Information provided in Table 1 allow to the following considerations concerning each of the features presented.

Table 1. Descriptive Studies.

\begin{tabular}{|c|c|c|c|c|c|}
\hline Study & Country & Cancer Type & $n$ & $\begin{array}{l}\text { Positive } \\
\text { affect measures }\end{array}$ & Conclusion \\
\hline $\begin{array}{l}\text { Christie et } \\
\text { al., } 2009\end{array}$ & U.S.A. & $\begin{array}{l}\text { Prostate Can- } \\
\text { cer }\end{array}$ & 57 & $\begin{array}{l}\text { The Positive } \\
\text { and Negative } \\
\text { Schedule } \\
\text { (PANAS) }\end{array}$ & $\begin{array}{l}\text { To examine whether patients in- Discussing treatment options with physi- } \\
\text { volved in treatment decision mak- cians increased positive affect after } \\
\text { ing report better quality of life after treatment. } \\
\text { treatment. }\end{array}$ \\
\hline $\begin{array}{l}\text { Helgeson } \\
\text { \&Tomich } \\
2005\end{array}$ & U.S.A. & Breast Cancer & 491 & $\begin{array}{l}\text { The Positive } \\
\text { and Negative } \\
\text { Schedule } \\
\text { (PANAS) }\end{array}$ & $\begin{array}{l}\text { To compare the quality of life of Patients with recurrence had worse quali- } \\
\text { patients with recurrent breast can- ty of life, less positive affect, more gen- } \\
\begin{array}{l}\text { cer, survivors and controls. } \\
\text { eral fatigue and more intrusive avoidant } \\
\text { thoughts. }\end{array}\end{array}$ \\
\hline $\begin{array}{l}\text { Hirsh et } \\
\text { al., } 2012\end{array}$ & U.S.A. & Lung Cancer & 133 & $\begin{array}{l}\text { NEO-Five } \\
\text { Factor Inven- }\end{array}$ & $\begin{array}{l}\text { To examine the association of af- Positive affect was significantly associat- } \\
\text { fective experience and health- ed with greater levels of social function- }\end{array}$ \\
\hline
\end{tabular}




\begin{tabular}{|c|c|c|c|c|c|}
\hline Study & Country & Cancer Type & $n$ & $\begin{array}{l}\text { Positive } \\
\text { affect measures }\end{array}$ & Conclusion \\
\hline & & & & $\begin{array}{l}\text { tory (NEO- } \\
\text { FFI) - positive } \\
\text { and negative } \\
\text { affect }\end{array}$ & $\begin{array}{l}\text { related quality of life in lung cancer ing and general health, over and above } \\
\text { patients. } \\
\text { the effects of negative affect. }\end{array}$ \\
\hline $\begin{array}{l}\text { Hou et } \\
\text { al., } 2010\end{array}$ & China & $\begin{array}{l}\text { Colorectal } \\
\text { Cancer }\end{array}$ & 215 & $\begin{array}{l}\text { The Positive } \\
\text { and Negative } \\
\text { Schedule } \\
\text { (PANAS) }\end{array}$ & $\begin{array}{l}\text { To assess whether differential pat- PA mediated and moderated the associa- } \\
\text { terns of change in Positive Affect tions between increased symptom dis- } \\
\text { (PA) were associated with psycho- tress and anxiety and depressed mood. } \\
\text { logical distress. } \\
\text { Continuous physical symptom distress } \\
\text { reduces PA and reduced PA brought to } \\
\text { higher levels of anxiety and depressed }\end{array}$ \\
\hline
\end{tabular}
mood.

\begin{tabular}{|c|c|c|c|c|c|}
\hline $\begin{array}{l}\text { Lechner et } \\
\text { al., } 2006 \\
\text { (Study 1) }\end{array}$ & U.S.A. & Breast Cancer & 230 & $\begin{array}{l}\text { The affects } \\
\text { Balance Scale } \\
\text { (ABS) }\end{array}$ & $\begin{array}{l}\text { To examine associations between The high and low Benefit Finding re- } \\
\text { benefit finding and psychosocial ported higher positive affect and lower } \\
\text { adjustment } \\
\text { negative affect. }\end{array}$ \\
\hline $\begin{array}{l}\text { Lechner et } \\
\text { al., } 2006 \\
\text { (Study 2) }\end{array}$ & U.S.A. & Breast Cancer & 136 & $\begin{array}{l}\text { The affects } \\
\text { Balance Scale } \\
\text { (ABS) }\end{array}$ & $\begin{array}{l}\text { To examine associations between Benefit finding was stronger linked with } \\
\text { benefit finding and psychosocial positive outcomes than absence of nega- } \\
\text { adjustment } \\
\text { tives outcomes. }\end{array}$ \\
\hline $\begin{array}{l}\text { Manne et } \\
\text { al., } 2008\end{array}$ & U.S.A. & $\begin{array}{l}\text { Primary Gyne- } \\
\text { cological Can- } \\
\text { cer }\end{array}$ & 114 & $\begin{array}{l}\text { Positive affect } \\
\text { of Mental } \\
\text { Health Inven- } \\
\text { tory (MHI) }\end{array}$ & $\begin{array}{l}\text { To identify demographic, medical, Women who were less expressive of pos- } \\
\text { and psychological predictors of itive emotions were less able to find } \\
\text { well-being. } \\
\text { something positive in the cancer experi- } \\
\text { ence and reported poorer adaptation. }\end{array}$ \\
\hline $\begin{array}{l}\text { Pinquart } \\
\text { et al., } 2007\end{array}$ & Germany & $\begin{array}{l}\text { Non Hodg- } \\
\text { kin's Lym- } \\
\text { phoma, Acute } \\
\text { Myelogenous } \\
\text { Leukemia, } \\
\text { Plasmocytome, } \\
\text { Colon Cancer. }\end{array}$ & 153 & $\begin{array}{l}\text { The Positive } \\
\text { and Negative } \\
\text { Schedule } \\
\text { (PANAS) }\end{array}$ & $\begin{array}{l}\text { To test whether perceived gains Finding positive consequences of cancer } \\
\text { and losses predicted change in psy- promoted psychological wellbeing. } \\
\text { chological well-being. }\end{array}$ \\
\hline $\begin{array}{l}\text { Rinaldis et } \\
\text { al., } 2009\end{array}$ & Australia & $\begin{array}{l}\text { Colorectal } \\
\text { Cancer }\end{array}$ & 1800 & $\begin{array}{l}\text { Bradburn's Af- } \\
\text { fect Balance } \\
\text { Scale }\end{array}$ & $\begin{array}{l}\begin{array}{l}\text { To develop a colorectal cancer Seeking Social Support was the only sub- } \\
\text { specific measure of coping. }\end{array} \\
\text { scale that predicted positive affect, and } \\
\text { hence the only subscale that accounted } \\
\text { for change. }\end{array}$ \\
\hline $\begin{array}{l}\text { Rinaldis et } \\
\text { al., } 2010\end{array}$ & Australia & $\begin{array}{l}\text { Colorectal } \\
\text { Cancer }\end{array}$ & 1750 & $\begin{array}{l}\text { Bradburn's Af- } \\
\text { fect Balance } \\
\text { Scale }\end{array}$ & $\begin{array}{l}\text { To identify benefits perceived by Benefit-finding domains accounted for } \\
\text { those diagnosed with colorectal significant amounts of variance in posi- } \\
\text { cancer. } \\
\text { tive affect. }\end{array}$ \\
\hline $\begin{array}{l}\text { Schroever } \\
\text { s et al., } \\
2008\end{array}$ & $\begin{array}{l}\text { Nether- } \\
\text { lands }\end{array}$ & $\begin{array}{l}\text { Lymphoma, } \\
\text { Breast Cancer, } \\
\text { Leukaemia, } \\
\text { Colorectal } \\
\text { Cancer, Lung } \\
\text { Cancer and } \\
\text { Prostate cancer }\end{array}$ & 108 & $\begin{array}{l}\text { The Positive } \\
\text { and Negative } \\
\text { Schedule } \\
\text { (PANAS) }\end{array}$ & $\begin{array}{l}\text { To test whether patients' ability to Focusing on pleasant issues was also sig- } \\
\text { manage goals is related to their nificantly associated with less negative af- } \\
\text { psychological well-being } \\
\text { fect. }\end{array}$ \\
\hline $\begin{array}{l}\text { Schroever } \\
\text { s et al., } \\
2011\end{array}$ & $\begin{array}{l}\text { Nether- } \\
\text { lands }\end{array}$ & $\begin{array}{l}\text { Lymphoma, } \\
\text { Breast cancer, } \\
\text { Leukemia, } \\
\text { Colorectal } \\
\text { Cancer, Lung } \\
\text { Cancer, Pros- } \\
\text { tate Cancer. }\end{array}$ & 108 & $\begin{array}{l}\text { The Positive } \\
\text { and Negative } \\
\text { Schedule } \\
\text { (PANAS) }\end{array}$ & $\begin{array}{l}\text { To investigate the relationship be- More positive changes were related to } \\
\text { tween positive and negative chang- more positive affect, whereas more nega- } \\
\text { es, and their association with posi- tive changes were related to more nega- } \\
\text { tive and negative affect. And to ex- tive affect and less positive affect. } \\
\text { amine the correlation of positive } \\
\text { and negative changes, specifically } \\
\text { the role of coping and goal reen- } \\
\text { gagement. }\end{array}$ \\
\hline $\begin{array}{l}\text { Shapiro, et } \\
\text { al., } 2010\end{array}$ & U.S.A. & $\begin{array}{l}\text { Breast cancer, } \\
\text { Lung cancer, } \\
\text { Colon Cancer, } \\
\text { Lymphoma, } \\
\text { Prostate Can- } \\
\text { cer, Leukemia, } \\
\text { Ovarian Can- } \\
\text { cer, Myeloma, } \\
\text { Pancreatic } \\
\text { Cancer, and }\end{array}$ & 283 & $\begin{array}{l}\text { Emotional ap- } \\
\text { proach coping } \\
\text { scales) - emo- } \\
\text { tional pro- } \\
\text { cessing and } \\
\text { emotional ex- } \\
\text { pression } \\
\text { (EACS) }\end{array}$ & $\begin{array}{l}\text { To examine relationships between That emotional processing was associat- } \\
\text { emotional adjustment and a num- ed with more distress and less positive } \\
\text { ber of coping styles and strategies emotion on some measures. That benefit } \\
\text { in people with cancer. } \\
\text { finding was associated with less depres- } \\
\text { sion and more positive affect. High levels } \\
\text { of hope were associated with low depres- } \\
\text { sion and high levels of happiness and } \\
\text { positive affect. }\end{array}$ \\
\hline
\end{tabular}




\begin{tabular}{|c|c|c|c|c|c|c|}
\hline Study & Country & Cancer Type & $n$ & $\begin{array}{l}\text { Positive } \\
\text { affect measures }\end{array}$ & Aim & Conclusion \\
\hline & & $\begin{array}{l}\text { widely dis- } \\
\text { persed among } \\
\text { a number of } \\
\text { other types of } \\
\text { cancer. }\end{array}$ & & & & \\
\hline $\begin{array}{l}\text { Voogt et } \\
\text { al., } 2005\end{array}$ & $\begin{array}{l}\text { Nether- } \\
\text { lands }\end{array}$ & $\begin{array}{l}\text { Breast Cancer, } \\
\text { Colorectal } \\
\text { Cancer, Ovari- } \\
\text { an Cancer, } \\
\text { Lung Cancer, } \\
\text { Prostate Can- } \\
\text { cer }\end{array}$ & 105 & $\begin{array}{l}\text { The Positive } \\
\text { and Negative } \\
\text { Schedule } \\
\text { (PANAS) }\end{array}$ & $\begin{array}{l}\text { To assess the levels of positive and } \\
\text { negative affect in patients with ad- } \\
\text { vanced cancer. }\end{array}$ & $\begin{array}{l}\text { Psychological distress of patients with } \\
\text { advanced cancer that seems to be mainly } \\
\text { caused by low levels of positive affect } \\
\text { and no by high levels of negative affect. }\end{array}$ \\
\hline
\end{tabular}

\section{Country}

Studies have been developed mainly across western countries (Australia, United Sates of America and Europe), but there are not samples providing patients from Latin cultures. Only one study was developed in China, but no more Asian populations have been assessed.

\section{Cancer Type}

Samples of patients with the more frequent cancers (breast, colorectal, gynaecological, lung and prostate) are represented in the studies that provide homogenous samples (nine studies) as well on those that provided mixed samples of patients with different tumours (five studies).

\section{Number of participants}

Sample sizes are very different, with a minimum of 57 prostate cancer patients, and a maximum of 1800 colorectal cancer patients. However a majority of the studies (seven studies) provided samples between 100-150 patients, whereas only four studies provide samples between $200-500$ patients. Two studies with colorectal cancer patients provide more than 1700 patients, although the sample used was the same in both papers.

\section{Positive Affect Measures}

Positive and Negative Affect Schedule (PANAS) is the most used assessment tool to assess positive and negative affect (seven studies). This enhances direct comparisons across studies. However, in the other seven studies, there is not a common questionnaire assessing affect and comparisons between results are more difficult.

$$
\text { Aim }
$$

Aims of the studies are very different. Only one study focused exclusively in assessing positive and negative affect levels (Voogt et al., 2005). The other studies assessed affect inside of a more widespread research focused on quality of life, and tried to ascertain which factors allow to greater levels of PA and lower levels of negative affect, or tried to identify the relationships between affect and other measures of the patients' psychological state.

\section{Conclusions}

Nine studies found that PA was significantly associated with greater levels of general health, social functioning, benefit finding, positive changes, and psychological well-being, as well as with low depression and less anxiety. Five studies suggested that PA increases when different activities are developed (i.e. discussing treatment options with physicians or seeking social support).

\section{Interventional Studies}

Table 2 resumes the main features of the nine interventional studies selected. It must be stated that two studies (Manne et al., 2007; Manne et al., 2010) used data providing from the same sample of patients. Following the same criteria used in Table 1, we will consider these researches as independent studies.

Table 2. Interventions Studies.

\begin{tabular}{|c|c|c|c|c|c|c|c|c|}
\hline Study & Country & $\begin{array}{l}\text { Cancer } \\
\text { Type }\end{array}$ & $n$ & $\begin{array}{l}\text { Positive } \\
\text { affect } \\
\text { measures }\end{array}$ & Intervention & & Follow-up & Conclusion \\
\hline $\begin{array}{l}\text { Antoni } \\
\text { et al., } \\
2001\end{array}$ & U.S.A. & $\begin{array}{l}\text { Breast Can- } \\
\text { cer }\end{array}$ & 100 & $\begin{array}{l}\text { The Profile } \\
\text { of Mood } \\
\text { States } \\
\text { (POMS) }\end{array}$ & $\begin{array}{l}\text { Cognitive Behavioral } \\
\text { Stress management } \\
\text { (CBSM) }\end{array}$ & $\begin{array}{l}10 \text { weekly } \\
2 \mathrm{hr} \text { sessions } \\
\text { structured } \\
\text { group inter- } \\
\text { vention }\end{array}$ & $\begin{array}{l}3 \text { month } \\
\text { and } 9 \\
\text { month }\end{array}$ & $\begin{array}{l}\text { The intervention also increases } \\
\text { participants' reports that having } \\
\text { breast cancer had made positive } \\
\text { contributions to their lives and it } \\
\text { increase generalized optimism. The }\end{array}$ \\
\hline
\end{tabular}




\begin{tabular}{|c|c|c|c|c|c|c|c|}
\hline Study & Country & $\begin{array}{l}\text { Cancer } \\
\text { Type }\end{array}$ & $n$ & $\begin{array}{l}\text { Positive } \\
\text { affect } \\
\text { measures }\end{array}$ & Intervention & Follow-up & Conclusion \\
\hline
\end{tabular}

intervention reduces depression but did not affect other measures. Also increase benefit finding an optimism (in women with low optimism at baseline)

Antoni U.S.A. Breast Can- 199 The Positive Cognitive Behavioral 10 weekly 1 year after The intervention reduces reports et al., cer States of Stress management $2 \mathrm{hr}$ sessions. randomiza- of social disruption and increases (PSOM) (CBSM) tion positive states of mind and benefit

The affects

Balance Scale

(ABS)

Badger U.S.A. $\quad$ Breast Can- 48 The Positive Counseling (TIP-C) 6 weekly tel- 1 month. Positive emotions increased and et al., cer and Negative focused on cancer ephone calls $\quad$ stress decreased; but results are in2005 Schedule education, role dis- (average 32.9 (PANAS) putes, social support, minutes). conclusive for negative emotions, and management of depression and fatigue.

depressive symp-

toms. Also, partners received three calls

Branstr Sweden Breast Can- 71 The Positive MBSR Program (Self 8-week 3 month Participants in the mindfulness om et cer, Gyneco- $\quad$ States of report mindfulness). mindfulness training group has significantly deal., logical Can- $\quad$ Mind training crease perceived stress and post$2010 \quad$ cer, $\mathrm{Lym}^{-} \quad$ (PSOM) traumatic avoidance symptoms and phatic Can- increase positive states of mind..

\begin{tabular}{lllllll}
\hline Danhau U.S.A. & Breast Can- & 44 & The Positive Ryoga classes. No 10 weekly & No & Women with higher NA and lower
\end{tabular}
er et al., cer and Negative home yoga practice 75-minute $\quad$ emotional well-being obtain great$2009 \quad$ Schedule was instructed nor er benefit from RY. PA increase in (PANAS) required. $\quad$ RY group. In depression scale and mental health scale are also better in RY group after treatment.

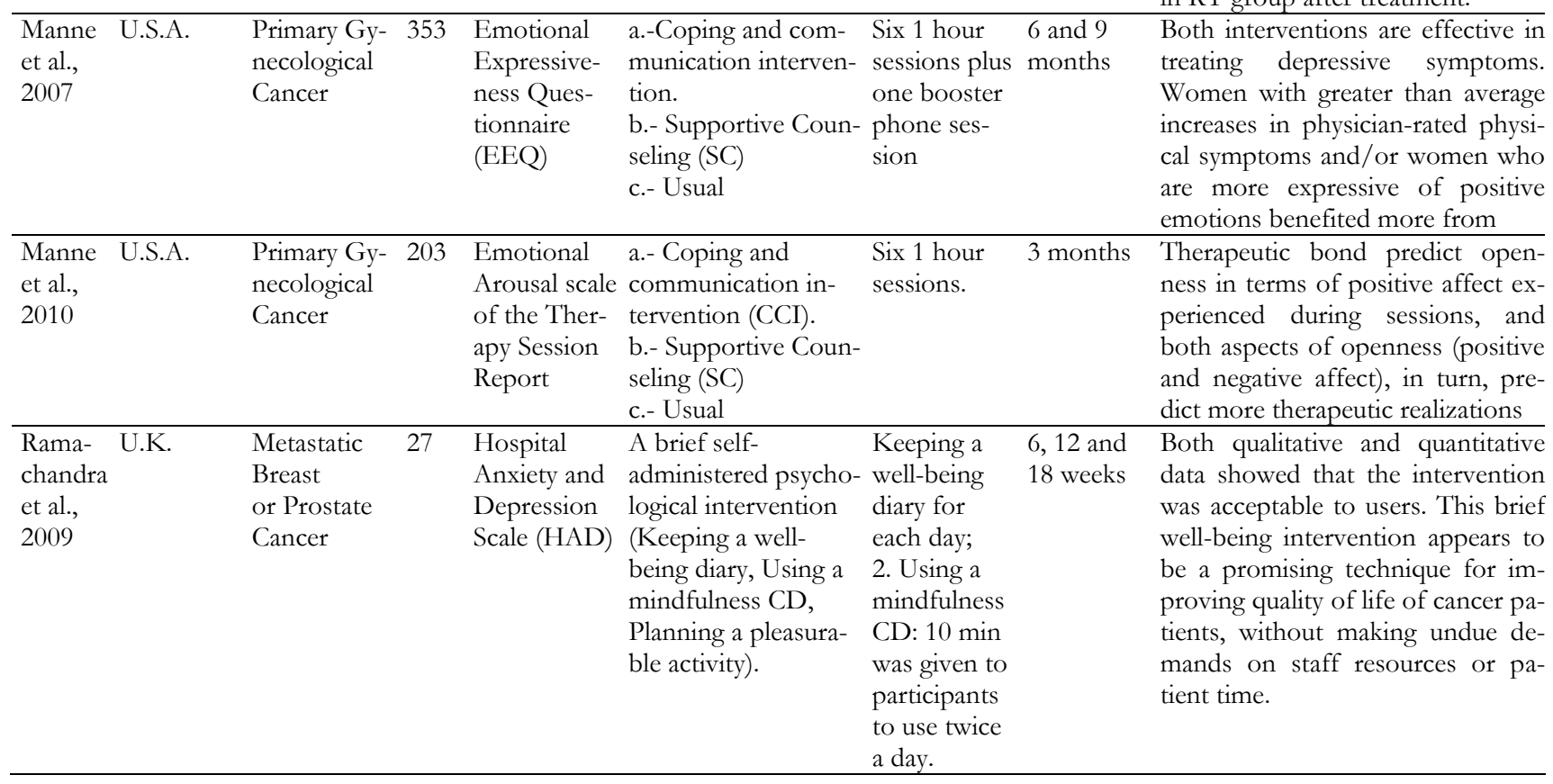




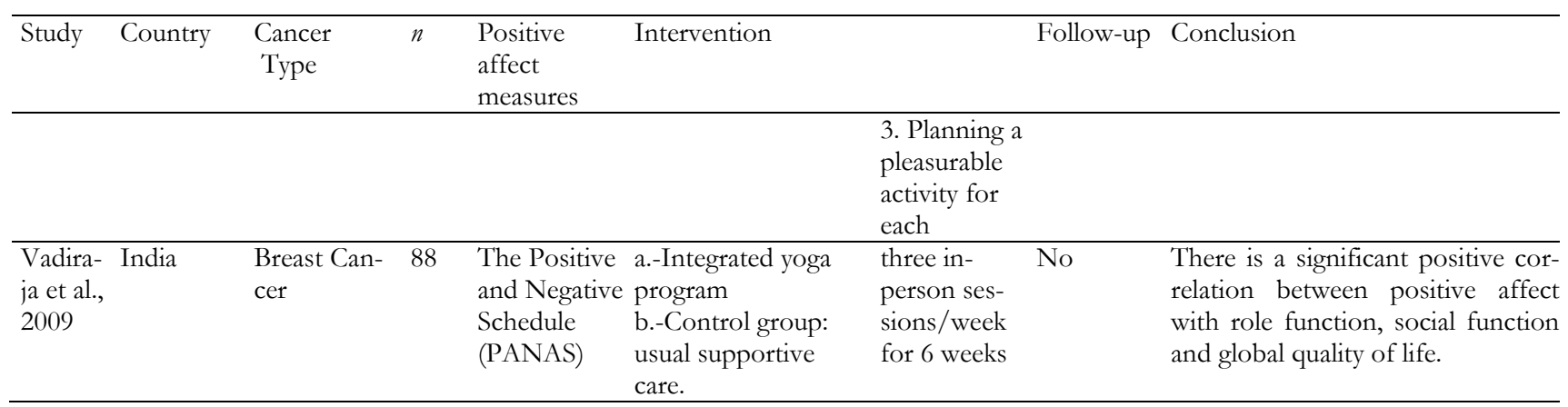

\section{Country}

Studies were mainly developed in western countries, mainly in United Sates of America (U.S.A.). Two studies were developed in Non-Latin European countries, whereas only one study was developed in Asian patients.

\section{Cancer Type}

Most of studies enrolled only female patients, with breast cancer patients representing the most commonly recruited patient group. Five studies enrolled patients with breast cancer and two studies recruited primary gynecological cancer patients. One study used mixed types of cancer for psychological intervention but included only one man and seventy women. Finally, only Ramachandra's study (Ramachandra, Booth, Pieters, Vrotsou, \& Huppert, 2009) included both women (metastatic breast cancer) and men (metastatic prostate cancer). Interventions have been applied at different moments across the evolution of the oncological disease. One study used patients who were not undergoing radiation or chemotherapy as current treatment (Branstrom, Kvillemo, Brandberg, \& Moskowitz, 2010). Six studies were developed in patients who were receiving radiation or chemotherapy treatment (Antoni et al., 2001, 2006; Badger et al., 2005; Manne et al., 2007, 2010; Vadiraja et al., 2009). One study used both breast cancer patients under treatment or without treatment (Danhauer et al., 2009). One study used patients with advanced cancer and it does not indicate which kind of treatment was applied (Ramachandra et al., 2009).

\section{Number of participants}

There were three studies in this review with less than 50 patients; three studies which included samples between 50 100 patients, and only three studies with more than $100 \mathrm{pa}-$ tients.

\section{Measures}

Although PANAS is the most used tool, (three studies), some other questionnaires and strategies have been used. Thus, it is more difficult than in the case of descriptive stud- ies to achieve comparisons from the affective state of the different patients assessed.

\section{Type of intervention}

There were different types of psychological interventions. Two of them used cognitive-behavioral stress management intervention; four of them applied counseling and education interventions; two studies were based on yoga programs and one study developed a mindfulness training program.

\section{Number of sessions}

There were five studies in this review which applied a program with 6 weekly sessions, one study with 8 weekly sessions and three studies with 10 weekly sessions.

\section{Follow up}

Some studies have reported results at different follow-up points. Two studies assessed patients immediately after the intervention (Danhauer et al., 2009; Vadiraja et al., 2009); one study collected data one month after treatment (Badger et al., 2005); and two studies developed a three-month follow-up (Branstrom et al., 2010; Manne et al., 2010). Two studies made assessments at two follow-up points: 3 and 9 months (Antoni et al., 2001), and 6 and 9 months (Manne et al., 2007). One study developed a 1-year follow-up (Antoni et al., 2006). Follow-up was not allowed in one study (Ramachandra et al., 2009) since patients had and advanced stage disease and some of them died even during the intervention phase.

\section{Conclusions}

The overall results from interventional studies suggest that the interventions described can be recommended for improving patient's levels of PA. However, information about the effect size obtained with each intervention is not provided. 


\section{Discussion}

The number of studies about PA in cancer patients published during the last ten years is scarce. Thus, only limited conclusions and considerations can be allowed. There are even a small number of studies in CRC patients, and any intervention study was specifically addressed to CRC patients. Thus, it is difficult to state considerations about the role of PA in CRC patients. Because of that, we will discuss the features that can be followed from the present review without considering the kind of tumour, and we will offer some suggestions which could be useful for CRC patients. In spite of that, one contribution of our study is to show that research about PA in CRC patients is largely needed.

\section{Descriptive Papers}

Although it seems that PA is related with higher levels of well-being and that social support and benefit finding increase PA, more studies that include samples providing from other countries in America, Asia and Europe are needed to replicate these results and to confirm that there are not cultural differences.

Since patients assessed had different kind of tumours, it can be suggested that the relationship between PA and wellbeing can be found across all cancer patients. More than this, since the studies with larger samples included CRC patients (Rinaldis et al., 2009, Rinaldis et al., 2010), it should be stated that this relationship is strong in this kind of patients. However, the studies do not provide enough evidence about whether cancer stage or kind of treatment could influence in the PA and well-being relationship. Thus, further studies which analyze these features are needed.

The fact that PANAS was the most used tool to assess positive and negative affect does not warrant that all studies provide comparable data, since some of them did not report the mean average of the sample and offered only the change levels in the scales across the longitudinal measures. For those studies which used the PANAS with the same scale range and provide mean rates for the sample, negative affect levels were low (between 15 and 19 in a 10-50 scale) and PA levels were moderate (between 27 and 33 in a 10-50 scale). These rates have also been observed in a sample of Spanish breast cancer patients (Bellver, Sánchez-Cánovas, Santaballa et al., 2009). Since these studies included different kind of tumours, it can be suggested that negative affect is not an outstanding feature in cancer patients. When questionnaires other than PANAS have been used, results are slightly different. Shapiro, McCue, Heyman, Dey and Haller (2010) reported moderate to high levels of PA (a mean range of 9.47 in a 0-12 range scale). Although these data suggest that PA in cancer patients is not absent, it could be possible that different profiles of negative and PA rates appear at different stages of the disease, and this possibility cannot be excluded since more studies which analyze this question should be developed.
In any case, the majority of studies reveal that changes in PA are best predictor of changes in quality of life and illness adaptation than changes in negative emotions. Nevertheless, an alternative explanation would be that the negative levels are lower and have less room for change. Possibly the most useful measure might be the positivity ratio developed by Fredrickson \& Losada (2005), that consist in assess not absolute levels but the ratio between experienced positive and negative affect. This measure has been used successfully in other fields (Fredrickson, Cohn, Coffey, Pek, \& Finkel, 2008; Cohn, Fredrickson, Brown, Mikels, \& Conway, 2009).

As it has previously stated, it seems that PA is clearly related with higher levels of well-being and that social support and benefit finding increase PA. However, since studies have not always addressed to assess positive and negative affect as the main purpose of the research, there are still some features which need further study (i.e. whether levels of affect differ between male and female patients, or whether changes in these levels across the disease evolution which reached statistical significance allow to clinical changes that could be also relevant to enhance well-being of patients). Thus, studies focused on the accurate assessment of positive and negative affect and their rate are required, and links between PA and long-term changes in patient's feelings, such as posttraumatic growth, should be considered (Vázquez \& Castilla, 2007).

\section{Intervention Studies}

In most studies, interventions have been addressed to breast cancer patients (Antoni et al., 2001, 2006; Badger et al., 2005; Danhauer et al., 2009; Vadiraja et al., 2009), with ginecological cancer patients also as an important sample (Manne et al., 2007, 2010). Only just one intervention study with mixed sample (Branstrom et al., 2010) Only twenty four prostatic male cancer patients (Ramachandra et al., 2009) participated in one of the studies revised. It can be concluded that little is known about how useful these interventions should be in other kind of tumors and/or in male cancer patients in general. Although it can be expected that these results could be generalized to other samples of cancer patients, research which includes patients (specially male patients) with other kind of tumors must be developed. There are no data about CRC patients. Thus, specific research for this kind of tumor (the third common cancer) is needed.

Most studies were developed in patients undergoing current treatment and with larger expectation of survival. Thus, it can be concluded that interventions should be useful in these situations. However some studies suggest that interventions should be also useful in advanced disease (Ramachandra et al., 2009) and in patients at disease-free interval (Branstrom et al., 2010) although more studies should be developed.

Concerning the size sample, intervention groups ranged between 22 and 132 participants in randomized studies. These sizes can be considered as suitable in randomized de- 
signs if we keep in mind that studies were developed in homogeneous samples with the same diagnosis. However, it must be pointed out that two studies used different number of participants belonging to the same sample of breast cancer patients (Antoni et al., 2001, 2006). Thus, it can be considered that only seven randomized trials have been developed. On the other hand, Manne et al., study, (2010) used the same data for a secondary analysis which did not use a randomized trial design. Although more research is needed, overall, the numbers of studies published provide more than some preliminary results and the following comments about the usefulness of the interventions based on enhance PA in cancer patients can be stated.

Type of interventions applied is mixed. Moreover, the descriptions are generic on the general direction of therapy, but there is no detailed description of its elements, although one can speculate that two main categories of strategies should be stated: cognitive and counseling based interventions (including cognitive behavioral stress management, education and counseling), and those which some authors call "mind-body therapies" (yoga and mindfulness). Whatever the case, results obtained suggest that PA is increased and quality of life is improved when applied to patients undergoing current treatment, even in cases of advanced disease (Ramachandra et al., 2009).

Interventions always used weekly sessions, ranging from 6 to 10 weeks. It can be concluded that no more than one weekly session is needed, although it should be investigated in which cases a 6 -week or a 10 -week schedule should be recommended. It seems that interventions which use mainly counseling strategies are shorter than those using cognitive behavioral management techniques. Since increased PA is achieved on both cases, further research is needed in order to know which schedule provides a greater and/or lasting therapeutic effects or which schedule offers the best costbenefit intervention.

Follow-up assessments suggest that therapeutic effects are maintained once the treatment has finished. In general, the studies showed that psychological intervention can produce substantial and durable effects on measures representing recovery of social functioning, reduction of negative affect, and increases in positive experiences. Although one might argue that the intervention's immediate impact on reports of benefit finding simply represents socially desirable responding, such an argument is far less persuasive for follow-ups. It is important to check whether such consolidation of psychological intervention is a reliable phenomenon and how durable it is across time. Accordingly, it is necessary that more studies follow participants for longer periods after the psychosocial intervention comes to its conclusion.

Overall, results suggest that all interventions have shown to be useful to increase PA and decrease negative affect. However, which kind of intervention should be recommended for which patients? Not all patients are able to develop some strategies or program schedules. For example, some patients at Ramachandra et al. (2009) study dropped out arguing that the intervention was not for them. Thus, research comparing different kinds of interventions in the same kind of patients (as it was developed in Manne et al. (2007) study is needed in order to clarify which patients should benefit from each kind of intervention.

\section{Integration between descriptive and interventional studies and implications for further studies and clin- ical interventions.}

There is a majority of studies developed in western countries and cultures. Studies on other populations are needed to know whether factors which seem allow to better levels of affect can be extended to other cultural settings. In the same sense, it must be confirmed in different cultural settings whether enhancing PA would allow to increase wellbeing in CRC patients. For example, in a study with Spanish breast cancer patients which received a psychological intervention (Bellver et al., 2009), it was observed that improvements in PA and decreases in negative affect where greater in patients with lower levels of well-being, and that these effects must be obtained at the first intervention session. In those cases where the first session did not provide improvements, these cannot be obtained in the following sessions of the intervention program. Results like that not only reveal that cultural differences can be found, but also that more knowledge about how psychological interventions produce beneficial effects in cancer patients is needed.

On the other hand, there is a methodological limitation that must be considered mainly in intervention studies: participants could be a biased sample that could not be represent the cancer patients population and, on the other hand, data did not include an important number of patients (ranging from 27 to 353) which rejected to participate or who dropped out from the studies. There was one study which did not indicate whether some patients dropped out of the studies (Badger et al., 2005). This is an important feature that should be analyzed in order to know whether this attrition rates are random or whether there are some reasons to explain why patients reject some therapeutic assistance that should be useful for them.

In spite of these considerations, some final guidelines can be suggested. Although there are results obtained in larger sizes in descriptive studies with CRC patients, and that it can be suggested that the relationships between PA and psychological well-being are strong, it is not clear that CRC patients have the same profile of the other kind of patients concerning their positive and negative affect levels, and much more research is still needed.

The same considerations can be stated concerning factors that should increase PA, although both cognitivecounseling interventions and mind-body interventions seem to enhance PA and decrease negative affect, mainly in women. However, it is not clear whether all patients should be able to follow therapeutic guidelines stated by these two main types of interventions. On the other hand, since it 
seems that weekly sessions are the best schedule, it is not still known how many weeks are needed to achieve the best cost-benefit schedule. Our focus of interest (CRC patients) has not been satisfied, since no intervention studies with this kind of patients have been developed. Thus, a first research addressed to assess whether PA can be enhanced using

\section{References}

American Cancer Society (2011) Colorectal Cancer Facts and Figures 2011-2013. Atlanta: American Cancer Society, 2011. Retrieved from http://www.cancer.org/, accessed on 01/11/2011.

Antoni, M. H., Lechner, S. C., Kazi, A., Wimberly, S. R., Sifre, T., Urcuyo, K. R., et al. (2006). How stress management improves quality of life after treatment for breast cancer. Journal of Consulting and Clinical Psychology, 74(6), 1143-1

Antoni, M. H., Lehman, J. M., Kilbourn, K. M., Boyers, A. E., Culver, J. L., Alferi, S. M., et al. (2001). Cognitive-behavioral stress management intervention decreases the prevalence of depression and enhances benefit finding among women under treatment for early-stage breast cancer. Health Psychology, 20(1), 20-32.

Aspinwall, L. G. \& MacNamara, A. (2005). Taking positive changes seriously - Toward a positive psychology of cancer survivorship and resilience. Cancer, 104(11), 2549-2556.

Badger, T., Segrin, C., Meek, P., Lopez, A. M., Bonham, E. \& Sieger, A. (2005). Telephone interpersonal counseling with women with breast cancer: Symptom management and quality of life. Oncology Nursing Forum, 32(2), 273-279.

Bellver, A., Sánchez-Cánovas, J., Santaballa, A., Munárriz, B., Pérez-Fidalgo, J. A., \& Montalar, J. (2009). Mujeres con cáncer de mama: evaluación del afecto positivo y negativo y valoración de un programa de intervención psicológica en el ámbito hospitalario. Psicooncología, 6(1), 139-154.

Blasco, T., Pallarés, C., Alonso, C. \& López López, J. J. (2000). The role of anxiety and adaptation to illness in the intensity of postchemotherapy nausea in cancer patients. The Spanish Journal of Psychology, 3(1), 47-52.

Branstrom, R., Kvillemo, P., Brandberg, Y. \& Moskowitz, J. T. (2010). Selfreport Mindfulness as a Mediator of Psychological Well-being in a Stress Reduction Intervention for Cancer Patients-A Randomized Study. Annals of Behavioral Medicine, 39(2), 151-161.

Cameron, L. D., Booth, R. J., Schlatter, M., Ziginskas, D., \& Harman, J.E. (2007). Changes in emotion regulation and psychological adjustment following use of a group psychosocial support program for women recently diagnosed with breast cancer. Psycho-Oncology, 16, 171-180.

Christie, K. M., Meyerowitz, B. E., Giedzinska-Simons, A., Gross, M., \& Agus, D. B. (2009). Predictors of affect following treatment decisionmaking for prostate cancer: conversations, cognitive processing, and coping. Psycho-Oncology, 18(5), 508.

Cohn, M. A., Fredrickson, B. L., Brown, S. L., Mikels, J. A. \& Conway, A. M. (2009). Happiness Unpacked: Positive Emotions Increase Life Satisfaction by Building Resilience. Emotion, 9(3), 361-368.

Danhauer, S. C., Mihalko, S. L., Russell, G. B., Campbell, C. R., Felder, L., Daley, K., et al. (2009). Restorative yoga for women with breast cancer: findings from a randomized pilot study. Psycho-Oncology, 18(4), 360-368.

Ferlay J, Shin H. R., Bray F., Forman D., Mathers C. \& Parkin, D. M. (2008). GLOBOCAN 2008 v1.2, Cancer Incidence and Mortality Worldwide: IARC CancerBase No. 10 [Internet]. Lyon, France: International Agency for Research on Cancer; 2010. Retrieved from http://globocan.iarc.fr

Fitzell, A., \& Pakenham, K. I. (2010). Application of a stress and coping model to positive and negative adjustment outcomes in colorectal cancer caregiving. Psycho-Oncology, 19(11), 1171-1178.

Fredrickson, B. L., Cohn, M. A., Coffey, K. A., Pek, J. \& Finkel, S. M. (2008). Open Hearts Build Lives: Positive Emotions, Induced Through Loving-Kindness Meditation, Build Consequential Personal Resources. Journal of Personality and Social Psychology, 95(5), 1045-1062.

Fredrickson, B. L., \& Losada, M. F. (2005). Positive affect and the complex dynamics of human flourishing. American Psychologist, 60(7), 678-686.

Frijda, N. H. (2009). Emotions, individual differences and time course: Reflections. Cognition and Emotion, 23(7), 1444-1461. some kind of psychological intervention, in CRC patients is needed. Meanwhile, interventions addressed to enhance PA can be applied to CRC patients who want to receive it, since data provided by this review suggest that these interventions should be useful.

Greer, S. (2008). CBT for emotional distress of people with cancer: some personal observations. Psycho-Oncology, 17, 170-173.

Hamer, M., Chida, Y. \& Molloy, G. J. (2009). Psychological distress and cancer mortality. Journal of Psychosomatic Research, 66, 255-258.

Helgeson, V. S., \& Tomich, P. L. (2005). Surviving cancer: A comparison of 5-year disease-free breast cancer survivors with healthy women. PsychoOncology, 14(4), 307-317.

Hirsch, J. K., Floyd, A. R. \& Duberstein, P. R. (2012) Perceived health in lung cancer patients: the role of positive and negative affect. Quality of Life Research, 21, 187-194.

Hou, W. K., Law, C. C., \& Fu, Y. T. (2010). Does change in positive affect mediate and/or moderate the impact of symptom distress on psychological adjustment after cancer diagnosis? A prospective analysis. Psychology and Health, 25(4), 417-431.

Koenig, H. G. (2000). Positive emotions, physical disability, and mortality in older adults. Journal of the American Geriatrics Society, 48(11), 1525-1526.

Lechner, S. C., Carver, C. S., Antoni, M. H., Weaver, K. E., \& Phillips, K. M. (2006). Curvilinear associations between benefit finding and psychosocial adjustment to breast cancer. Journal of Consulting and Clinical Psycholo$g y, 74(5)$.

Listing, M., Reisshauer, A., Krohn, M., Voigt, B., Tjahono, G. Becker, J., Klapp, B. F., \& Rauchfuss, M. (2009). Massage therapy reduces physical discomfort and improves mood disturbances in women with breast cancer. Psycho-Oncology, 18, 1290-1299.

Manne, S. L., Edelson, M., Bergman, C., Carlson, J., Rubin, S., Rosenblum, N., et al. (2007). Coping and communication-enhancing intervention versus supportive counseling for women diagnosed with gynecological cancers. Journal of Consulting and Clinical Psychology, 75(4), 615-628.

Manne, S., Rini, C., Rubin, S., Rosenblum, N., Bergman, C., Edelson, M., et al. (2008). Long-term trajectories of psychological adaptation among women diagnosed with gynecological cancers. Psychosomatic Medicine, $70(6), 677-68$.

Manne, S., Winkel, G., Zaider, T., Rubin, S., Hernandez, E., \& Bergman, C. (2010). Therapy Processes and Outcomes of Psychological Interventions for Women Diagnosed With Gynecological Cancers: A Test of the Generic Process Model of Psychotherapy. Journal of Consulting and Clinical Psychology, 78(2), 236-248.

Millar, K., Purushotham, A. D., McLatchie, E., George, W. D., \& Murray, G. D. (2005). a 1-year prospective study of individual variation in distress and illness perceptions after treatment for breast cancer. Journal of Psychosomatic Research, 58, 335-342.

Nekolaichuk C, Cumming C, Turner J, Yushchyshyn A, \& Sela R. (2011). Referral patterns and psychosocial distress in cancer patients accessing a psycho-oncology counseling service. Psycho-Oncology, 20, 326-332.

Nishigaki, M., Oya, M., Ueno, M., Arai, M., Yamaguchi, T., Muto, T. et al. (2007). The influence of life stage on psychosocial adjustment in colorectal cancer patients. Journal of Psychosocial Oncology, 25, 71-87.

Northouse, L. L., Mood, D., Templin, T., Mellon, S., \& George, T. (2000). Couples' patterns of adjustment to colon cancer. Social Science and Medicine, 50(2), 271-284.

Ostir, G. V., Markides, K. S., Black, S. A., \& Goodwin, J. S. (2000). Emotional well-being predicts subsequent functional independence and survival. Journal of the American Geriatrics Society, 48(5), 473-478.

Penninx, B., Guralnik, J. M., Bandeen-Roche, K., Kasper, J. D., Simonsick, E. M., Ferrucci, L. et al. (2000). The protective effect of emotional vitality on adverse health outcomes in disabled older women. Journal of the American Geriatrics Society, 48(11), 1359-1366.

Pinquart, M., Frohlich, C., \& Silbereisen, R. K. (2007). Cancer patients' perceptions of positive and negative illness-related changes. Journal of Health 
Psychology, 12(6), 907-921.

Ramachandra, P., Booth, S., Pieters, T., Vrotsou, K., \& Huppert, F.A. (2009). A brief self-administered psychological intervention to improve well-being in patients with cancer: results from a feasibility study. PsychoOncology 18, 1323-1326.

Reynolds, J. S., \& Perrin, N. A. (2004). Mismatches in social support and psychosocial adjustment to breast cancer. Health Psychology, 23(4), 425430.

Rinaldis, M., Pakenham, K. I., \& Lynch, B. M. (2010). Relationships between quality of life and finding benefits in a diagnosis of colorectal cancer. British Journal of Psychology, 101, 259-275.

Rinaldis, M., Pakenham, K. I., Lynch, B. M., \& Aitken, J. F. (2009). Development, confirmation, and validation of a measure of coping with colorectal cancer: a longitudinal investigation. Psycho-Oncology, 18(6), 624-633.

Scherer, M., \& Herrmann-Lingen, C. (2009). Single item on positive affect is associated with 1-year survival in consecutive medical inpatients. General Hospital Psychiatry, 31(1), 8-13.

Schofield, P., Ball, D., Smith, J. G., Borland, R., O'Brien, P., Davis, S., et al. (2004). Optimism and survival in lung carcinoma patients. Cancer, 100(6), 1276-1282.

Schroevers, M., Kraaij, V., \& Garnefski, N. (2008). How do cancer patients manage unattainable personal goals and regulate their emotions? British Journal of Health Psychology, 13, 551-562.
Schroevers, M. J., V. Kraaij, \& Garnefsky, N. (2011). Cancer patients' experience of positive and negative changes due to the illness: relationships with psychological well-being, coping, and goal reengagement. PsychoOncology, 20(2), 165-172.

Shapiro, J. P., McCue, K., Heyman, E. N., Dey, T., \& Haller, H. S. (2010) Coping-related variables associated with individual differences in adjustment to cancer. Journal of Psychosocial Oncology 28(1), 1-22.

Simon, A. E., Thompson, M. R., Flashman, K., \& Wardle, J. (2009). Disease stage and psychosocial outcomes in colorectal cancer. Colorectal Disease, 11(1), 19-25.

Vadiraja, H. S., Rao, M. R., Nagarathna, R., Nagendra, H. R., Rekha, M., Vanitha, N., et al. (2009). Effects of yoga program on quality of life and affect in early breast cancer patients undergoing adjuvant radiotherapy: a randomized controlled trial. Complement Ther Med, 17(5-6), 274-280.

Vázquez, C. \& Castilla, C. (2007). Emociones positivas y crecimiento postraumático en cáncer de mama. Psicooncología, 4(2-3), 385-404.

Voogt, E., Van der Heide, A., Van Leeuwen, A. F., Visser, A. P., Cleiren, M., Passchier, J., et al. (2005). Positive and negative affect after diagnosis of advanced cancer. Psycho-Oncology, 14(4), 262-273.

Wright, E. P., Kiely, M. A., Lynch, P., Cull, A., \& Selby, P. J. (2002). Social problems in oncology. British Journal of Cancer, 87(10), 1099-1104.

(Article received: 12-10-2012; revised: 18-05-2013; accepted: 04-11-2013) 